\title{
PENGUATAN KEWENANGAN LEMBAGA BADAN PENGAWAS PEMILU DALAM PENEGAKAN HUKUM PEMILU
}

\author{
- Angelo Emanuel Flavio Seac dan Sirajuddin -
}

\begin{abstract}
Abstrak
Penelitian ini berangkat dari tingginya pelanggaran administrasi dan pidana dalam pemilu di Indonesia, sehingga perlu dilakukan sebuah pengkajian terhadap perlunya penguatan kewenangan Bawaslu dalam penyelenggaraan pemilu, agar dapat memperbaiki kualitas pemilu, dan menciptakan praktek penegakan hukum Pemilu yang baik di Indonesia. Untuk mengkaji hal tersebut, maka dalam penelitian ini digunakan jenis penelitian yuridis normatif, dengan menggunakan pendekatan statute approach, historical approach, conseptual approach, case approach, dan comparative approach. Untuk kemudian bahan hukum yang terkumpul dianalisis secara deskriptif kualitatif. . Penguatan kewenangan ini halus dilakukan dengan menyertai perbaikan dibeberapa aspek vital lainnya. Yakni perbaikan regulasi mengenai kelembagaan dan penyelenggaran pemilu yang memberikan ruang ketegasan pada Bawaslu yang lebih ideal dalam penegakan hukum pemilu.
\end{abstract}

Kata kunci: Bawaslu, Penguatan Kewenangan, Penegakan Hukum, Pemilu.

\section{Abstract}

This study is based on the high administrative and criminal violations in the elections in Indonesia, so an assessment is needed to strengthen the authority of Bawaslu in the implementation of elections, in order to improve the quality of elections, and create good electoral law enforcement practices in Indonesia. To study this matter, hence in this research a normative juridical research, using approach statute approach, historical, conseptual, case, and comparative approaches was employed. Then the collected legal materials were descriptively and qualitatively analyzed. The strengthening of this delicate authority is accomplished by accompanying improvement in some other vital aspects such as the regulatory improvements on the institutional and electoral arrangements that give Bawaslu a more assertiveness space that is more ideal in the electoral law enforcement.

Keywords: Bawaslu, Strengthening Authority, Law Enforcement, Election.

\section{PENDAHULUAN}

Dalam Undang-Undang Dasar Negara Republik, pelaksanaan Pemilu di Indonesia merupakan sebuah pencerminan dari penerapan konsep demokrasi yang ditegaskan di dalam UUD 1945 yakni Pasal 1 ayat (2) yang menyatakan bahwa "kedaulatan berada di tangan rakyat dan dilaksanakan menurut UndangUndang Dasar", ${ }^{1}$ yang kemudian kembali dipertegas dalam pasal $22 \mathrm{E}$ ayat (1) yang menyebutkan bahwa "pemilihan umum diselenggarakan, secara langsung, umum, bebas, dan rahasia". Dalam hal ini bahwasannya sebagai Negara Demokrasi, tidak terlepas dengan adanya penyelenggaran Pemilu sebagai bentuk penjaminan kesinambungan pembanguan nasional yang notabene merupakan salah satu wahana

${ }^{1}$ Lihat pasal 1 ayat (2) Undang-Undang Dasar Negara Republik Indonesia 1945. pelaksanaan kedaulayan rakyat. Patut diketahui bahwa pemilihan umum yang dilakukan secara langsung adalah bentuk wujud nyata dari kedaulatan rakyat yang bertujuan untuk menghasilkan Pemerintahan Negara yang Demokratis dan sesuai dengan Nilai-nilai dari Pancasila dan Undang-Undang Dasar 1945, sehingga terlaksananya Pemilu yang baik dapat menunjukkan secara tidak langsung perihal adanya suatu peningkatan demokrasi yang cukup baik.

Tentunya penyelenggaraan Pemilihan Umum tidak terlepas dari Lembaga kePemiluan yaitu Komisi Pemilihan Umum (KPU) dan Badan Pengawas Pemilu (Bawaslu) sesuai dengan Undang-Undang Nomor 15 Tahun $2011^{2}$ Tentang Penyelenggaraan Pemilu dan kedua lembaga tersebut memiliki peran yang cukup penting, salah

${ }^{2}$ UU No. 15 Tahun 2011 Tentang Penyelenggaraan Pemilu. 
satunya yaitu Bawaslu atau Badan Pengawas Pemilu, sehingga dalam hal meningkatkan dan memaksimalkan kualitas dari penyelenggaraan Pemilu yang memberikan kepastian terhadap tegaknya kedaulatan dan hak pilih dari masyarakat tentunya ditentukan oleh profesionalitas, kapabilitas, dan kredibilitas dari dua lembaga tersebut.

Sesuai dengan Undang-undang No. 15 Tahun 2011 selaras Peraturan Badan Pengawas Pemilihan Umum Republik Indonesia Nomor 2 Tahun $2015^{3}$ dengan menyebutkan bahwa ada tiga tugas dan kewenangan Bawaslu sebagai institusi pengawas Pemilu dalam konteks penegakan hukum Pemilu yakni sebagai berikut. Pertama, melaksanakan pengawasan terhadap seluruh tahap proses penyelenggaraan Pemilu dalam rangka pencegahan dan penindakan pelanggaran Pemilu. Kedua, menerima dan mengkaji laporan mengenai dugaan pelanggaran ketentuan administrasi pemilihan umum dan dugaan pelanggaran ketentuan pidana Pemilu. Terdapat tiga pihak dalam masyarakat yang diberi hak untuk mengajukan pengaduan Tiga pihak dalam masyarakat diberi hak untuk mengajukan pengaduan tentang dugaan pelanggaran Pemilu, yaitu Peserta Pemilu, Pemantau Pemilu yang terakreditasi, dan Pemilih Terdaftar. Bila laporan itu dipandang memiliki bukti awal yang memadai, Bawaslu meneruskan laporan dugaan pelanggaran tersebut kepada KPU/KPU Provinsi/ KPU Kabupaten-Kota apabila menyangkut dugaan pelanggaran ketentuan administrasi Pemilu atau kepada Kepolisian Republik Indonesia apabila menyangkut dugaan pelanggaran ketentuan pidana Pemilu. Ketiga, menyelesaikan sengketa administrasi pemilihan umum secara final dan mengikat kecuali untuk dua kasus sengketa. Kedua kasus yang dimaksud adalah sengketa administrasi penetapan peserta Pemilu dan sengketa penetapan daftar calon anggota DPR dan DPRD. Putusan Bawaslu mengenai keduajenis kasus ini tidak bersifat final karena KPU masih dapat mengajukan banding kepada Pengadilan Tinggi Tata Usaha Negara yang putusannya ber-

${ }^{3}$ Peraturan Badan Pengawas Pemilihan Umum Republik Indonesia Nomor 2 Tahun 2015 Tentang Perubahan atas Peraturan Badan Pengawas Pemilihan Umum Nomor 11 tahun 2014 Tentang Pengawasan Pemilihan Umum. sifat final. Sehubungan berlakunya UndangUndang Nomor 15 Tahun 2011 tentang Penyelenggara Pemilu (UU No. 15/2011) dan UndangUndang Nomor 8 Tahun 2012 tentang Pemilihan Umum Anggota Dewan Perwakilan Rakyat, Dewan Perwakilan Daerah, dan Dewan Perwakilan Rakyat Daerah (UU No. 8/2012). Kedua undang-undang tersebut sedikit banyak telah mengubah organisasi dan fungsi Bawaslu.

Dari penjelasan diatas mengenai tugas dan kewenangan dari Bawaslu sebagai institusi pengawas Pemilu terlihat sangat terbatas dalam memainkan peran yang lebih strategis lagi pada penyelenggaraan Pemilu. Selain itu, setiap kali Pemilu dilaksanakan selalu saja muncul isu tentang lemahnya penegakan hukum Pemilu. Isu ini berangkat dari kenyataan betapa banyak pelanggaran administrasi dan tindak pidana Pemilu yang tidak ditangani sampai tuntas. Dari sisi historis mengenai sepak terjang kinerja Bawaslu diawali pada masa transisi, yakni Pemilu 1999, lembaga pengawas Pemilu dijuluki sebagai tukang pembuat rekomendasi, tukang memberi peringatan, tidak bergigi, pemulung data, dan was-was melulu. Sedangkan pada Pemilu 2004, keberadaan pengawas Pemilu sekadar pelengkap penyelenggaraan Pemilu, karena kasus-kasus yang ditanganinya ternyata tidak dituntaskan lembaga lain. Lembaga pengawas Pemilu yang diperkuat organisasinya melalui pembentukan Bawaslu menjelang Pemilu 2009, sebagaimana diatur dalam Undang-Undang Nomor 22 Tahun 2007 tentang Penyelenggara Pemilihan Umum(UU No. 22/2007), ${ }^{4}$ sama sekali tidak mengubah persepsi buruk itu. Kehadirannya nyata, dan semakin banyak menyedot banyak anggaran negara, tetapi kegunaannya dipertanyaakan, dan efektivitas kerjanya diragukan.

Berdasarkan laporan Pengawasan Pemilu 2009 yang disusun Bawaslu menunjukkan, dalam Pemilu legislatif Bawaslu menerima 21.350 laporan pelanggaran, yang terdiri dari 15.341 laporan pelanggaran administrasi dan 6.019 laporan pelanggaran pidana. ${ }^{5}$

${ }^{4}$ UU No. 22/2007 diundangkan pada 19 April 2007.

${ }^{5}$ Didik Supriyatno, Veri Junadi, Devi Darmawan, Penguatan Bawaslu, Optimalisasi Posisi, Organisasi, dan Fungsi dalam Pemilu 2014, Perludem. 2012, hlm. 30-31. 
Setelah melakukan pengkajian terhadap laporan pelanggaran administrasi, Bawaslu mencatat 10.094 kasus mengandung pelanggaran administrasi. Laporan jenis ini diteruskan ke KPU, dan KPU menindaklanjuti 7.583 laporan, sisanya diabaikan. Selanjutnya Bawaslu mencatat 1.646 kasus yang benar-benar mengandung pelanggaran pidana yang kemudian diteruskan ke kepolisian. Ternyata pihak kepolisian hanya meneruskan 405 kasus ke kejaksaan, dan hanya 260 kasus yang dilimpahkan kejaksaan ke pengadilan. Akhirnya PN menjatuhkan 248 vonis dan PT menajutuhkan 62 vonis.

Selanjutnya berdasarkan laporan Pengawasan Pemilu 2014 yang disusun Bawaslu menunjukkan, dalam Pemilu legislatifdan Pemilu Presiden dan Wakil Presiden Bawaslu menerima 7.339 laporan pelanggaran administrasi dan 301 laporan pelanggaran pidana. ${ }^{6}$

Beberapa fakta kasus yang terjadi dilapangan sebagai bentuk pelanggaran administrasi dan pidana pada Pemilu 2014 yaitu: ${ }^{7}$

1. Kasus Calon Presiden Ir. Joko Widodo yang diduga melakukan kampanye di luar jadwal pada saat Pencabutan Nomor Urut Peserta Pemilu Presiden dan Wakil Presiden yang terjadi di Gedung KPU RI, dimana pada saat itu Joko Widodo (Terlapor) ketika diberikan kesempatan kepada KPU untuk memberikan sambutan mengacungkan jari telunjuk dan jari tengahnya dan mengatakan Salam Dua Jari. Hal tersebut dapat ditafsirkan oleh banyak pihak sebagai bentuk ajakan untuk memilihnya sehingga diartikan sebagai tindakan kampanye di luar jadwal.

2. Tim kampanye Paslon menghina paslon lain (terjadi di Provisi Papua).

3. Black Campaign: Provinsi DIY, Kota Kendari, Provinsi Jawa Barat dan Kabupaten Ciamis.

4. Kampanye Menggunakan Kendaraan Dinas: Kabupaten Barito Kuala.

5. Kampanye Dirumah dinas: Kota Bukittinggi.

${ }^{6}$ Dalam Bawaslu, "Laporan Hasil Pengawasan Pemilu Tahun 2014" dalam http://www.Bawaslu.go.id/id/hasil-pengawasanpemilu/laporan-hasil-pengawasan-pemilu-tahun-2014, diakses tgl. 19 Februari 2017, hlm. 99.

${ }^{7}$ Ibid. hlm. 52.
6. Dugaan pelanggaran money politics: Kabupaten Tana Datar, Kabupaten Tanah Bumbu, Kabupaten Halmahera Selatan, Kabupaten Konawe Selatan.

Seluruh laporan dan temuan pelanggaran tersebut telah diteruskan kepada KPU dan jajarannya untuk ditindaklanjuti. Berdasarkan catatan Pengawas Pemilu, tidak semua rekomendasi ditindaklanjuti oleh KPU dan jajarannya, nyatanya masih ada 612 (enam ratus dua belas) dugaan pelanggaran administrasi yang tidak ditindaklanjuti. Seluruh laporan dan temuan pelanggaran tersebut telah diteruskan kepada KPU dan jajarannya untuk ditindaklanjuti. Berdasarkan catatan Pengawas Pemilu, tidak semua rekomendasi ditindaklanjuti oleh KPU dan jajarannya. ${ }^{8}$

Selanjutnya Bawaslu mencatat 24 kasus yang benar-benar mengandung pelanggaran pidana, dimana dari 24 temuan dan laporan tindak pidana Pemilu tersebut, Pengawas Pemilu meneruskan tiga diantaranya kepada jajaran penyidik kepolisian. Ternyata dalam prosesnya diberhentikan oleh polisi sendiri. Karena berdasarkan kewenangan yang ada, dimana fungsi Bawaslu yang hanya sebagai "tukang pos", yakni menyampaikan rekomendasi adanya pelanggaran administrasi ke penyelenggara Pemilu, rekomendasi pelanggaran kode etik penyelenggara Pemilu ke DKPP, dan rekomendasi pelanggaran pidana ke kepolisian, tidak cukup memiliki kekuatan untuk memberikan dorongan maupun tekanan terhadap lembaga seperti KPU dan Kepolisian dalam hal menegakan hukum Pemilu seperti pelanggaran administratif maupun pelanggaran pidana dalam penyelenggaraan Pemilu. Kondisi di atas menjelaskan permasalahan efektifitas pelaksanaan tugas, wewenang dan kewajiban kelembagaan pengawas Pemilu dalam penyelenggaraan Pemilu terkait kecenderungan sikap KPU yang seringkali tidak mengindahkan rekomendasi kelembagaan pengawas Pemilu atas penanganan dugaan pelanggaran kode etik dan tindak lanjut penanganan pelanggaran administratif, sebagai dampak langsung lemahnya kewenangan kelembagaan pengawas Pemilu

\footnotetext{
${ }^{8}$ Ibid. hlm. 53
} 
dalam sistem penyelenggaraan kePemiluan, yang mengakibatkan mengemukanya berbagai permasalahan kePemiluan diantaranya manipulasi persyaratan pencalonan, invaliditas data pemilih, penyalahgunaan kewenangan serta penggelembungan hasil perolehan suara yang melibatkan pelaksana Pemilu. ${ }^{9}$

Persoalan utama pengawasan Pemilu adalah penegakan hukum namun walaupun secara resmi ditunjuk Undang-Undang, akan tetapi secara kelembagaan, Bawaslu seringkali ditempatkan dalam posisi serba dilematis. Di satu sisi, ekspektasi masyarakat sangat besar terhadap peran lembaga ini dalam mengawal berbagai tahapan Pemilu, namun, di sisi lain, keterbatasan kewenangan yang dimiliki membuat lembaga pengawas tidak dapat berfungsi sebagaimana yang diharapkan.

Keberadaan pengawas Pemilu dalam tinjauan politik dan hukum administrasi, bersifat penting untuk menghindari delegitimasi terhadap proses dan hasil pelaksanaan Pemilu, serta antisipasi perkembangan berbagai tindak pelanggaran kePemiluan berdasarkan tata hukum secara terpadu dan menyeluruh, guna perkuatan kepercayaan masyarakat ditengah-tengah berbagai permasalahan implementasi sistem kePemiluan. ${ }^{10}$ Pada bagian berikutnya, keberadaan pengawas Pemilu yang kuat tidak terlepas dari pentingnya mekanisme pengawasan demi terwujudnya Pemilu yang berkualitas. ${ }^{11}$

Selain itu ada pendapat dari Ramlan Surbakti $^{12}$ yang turut memberikan kontribusi pendapat mengenai pentingnya peran dari Bawaslu ini, bahwasannya ia menuturkan untuk menegakan hukum dan menyelesaikan sengketa Pemilu perlu dilakukan reformasi sistem penegakan hukum secara institusional. Reformasi institusional yang dimaksud adalah transformasi Bawaslu menjadi Komisi Penegak Hukum Pemilu (KPHP).

\footnotetext{
9 Lihat Putusan Mahkamah Konstitusi Nomor 108-109/ PHPU.B-VII/2009 tanggal 12 Agustus 2009, khususnya dalam bagian pertimbangan hukum putusan, yang menyatakan bahwa “...UU 22/2007 tidak atau kurang memberikan empowering kepada Badan Pengawas Pemilu (Badan Pengawas Pemilihan) beserta jajarannya sehingga pengawasan Pemilu tidak efektif dan sekedar sebagai formalitas..."

${ }^{10}$ Nurhidayat Sardini, 2009, Pedoman Pengawasan Pemilu, (Jakarta: Election-MDP), hlm. 3.

${ }^{11}$ Iwan Satriawan,Pengawasan Pemilukada oleh Rakyat, Jurnal Bawaslu Vo. 2 Edisi I Tahun 2016, hlm. 115.

${ }^{12}$ Ramlan Surbakti, "Penegakan Hukum Pemilu”, dalam Kompas, 16 Desember 2016, hlm. 3-5.
}

Beranjak dari pemaparan diatas, penulis merasa perlu untuk melakukan sebuah kajian terhadap pentingnya peranan Bawaslu dalam penegakan hukum terkait penyelenggaraan Pemilu di Indonesia, hal ini dilakukan untuk mengupayakan sebuah kesatuan format yang secara fungsional antara penegakan hukum dengan fungsi pengawasan, sehingga perlu adanya penguatan kewenagan terhadap Lembaga Pengawas Pemilu khususnya dalam penyelenggaraan Pemilu.

\section{PEMBAHASAN}

\section{A. Urgensi Penguatan Kewenangan Bawaslu Dalam Penegakan Hukum Pemilu}

\section{Pro Kontra Keberadaan Bawaslu}

Bawaslu yang dibentuk pada Pemilu 2009, diharapkan mampu memberikan jaminan penyelenggaran Pemilu yang jauh dari tingginya angka pelanggaran baik secara administrasi maupun pidana, namun dari sisi kinerja pada Pemilu 2009 ternyata tidak sesuai dengan yang diharapkan dan menguat isu pro dan kontra bahwa lembaga ini akan dibubarkan, akhirnya Bawaslu ini kemudian berlakunya Undang-Undang Nomor 15 Tahun 2011 tentang Penyelenggara Pemilu (UU No. 15/2011) dan Undang-Undang Nomor 8 Tahun 2012 tentang Pemilihan Umum Anggota Dewan Perwakilan Rakyat, Dewan Perwakilan Daerah, dan Dewan Perwakilan Rakyat Daerah (UU No. 8/2012). Kedua undang-undang tersebut sedikit banyak telah mengubah organisasi dan fungsi Bawaslu.Pertama, UU No. 15/2011 memperkuat organisasi Bawaslu dengan mengubah Panwaslu Provinsi menjadi Bawaslu Provinsi, yang berarti mengubah kelembagaan pengawas Pemilu provinsi yang tadinya bersifat sementara atau $A d$ Hoc, menjadi permanen. Kedua, UU No. 8/2012 menambah wewenang Bawaslu untuk menyelesaikan sengketa Pemilu. Sengketa yang diselesaikannya bukan sekadar sengketa antarpeserta Pemilu sebagaimana terjadi pada masa lalu, tetapi juga sengketa antara peserta Pemilu dengan penyelenggara Pemilu.

Sebelumnya, Putusan Mahkamah Konstitusi No. 11/PUU-VIII/2010 telah menempatkan Bawaslu sebagai lembaga mandiri, sebagaimana KPU. Dengan putusan ini, secara kelembagaan 
Bawaslu bukan lagi sebagai bagian dari KPU; Bawaslu juga tidak lagi dibentuk oleh KPU. Posisi Bawaslu adalah lembaga mandiri, kedudukannya sejajar dengan KPU, sama-sama sebagai lembaga penyelenggara Pemilu, yang bersifat nasional, tetap dan mandiri, seperti diatur oleh Pasal 22E Ayat (5) UUD 1945.

Perubahan regulasi terhadap bentuk dan kewenangan Bawaslu pada Undang-Undang Nomor 15 Tahun 2011 tentang Penyelenggara Pemilu (UU No. 15/2011) dan Undang-Undang Nomor 8 Tahun 2012 tentang Pemilihan Umum Anggota Dewan Perwakilan Rakyat, Dewan Perwakilan Daerah, dan Dewan Perwakilan Rakyat Daerah (UU No. 8/2012), merupakan sebuah wujud penyempurnaan dan langkah nyata dalam upaya memperbaiki kualitas Pemilu di Indonesia, karena dalam Pemilu tahun 2009 belum berjalan secara optimal, sehingga diambilah perbaikan dalam upaya mewujudkan sebuah tujuan untuk meningkatkan kualitas penyelenggara Pemilu. ${ }^{13}$ Yang tidak lain, Bawaslu ini dilatarbelakangi karena ingin Pemilu-Pemilu yang akan datang adalah sebuah Pemilu yang betul-betul berkualitas, artinya bisa dijamin segala sesuatunya menjadi sangat terukur, dimana penyelenggaraan pemilihan umum mengacu pada aturan-aturan landasan hukum penyelenggaraan Pemilu, undang-undang Pemilu, serta undangundang terkait lainnya, di mana tidak ada lagi ada aturan yang tidak bisa dilaksanakan.

Namun efektifitas dari kehadiran Bawaslu sebagai salah satu lembaga penyelenggara Pemilu, yang berfungsi dalam ranah pengawasan, ini kembali dipertanyakan dalam penyelenggaran Pemilu 2014 dimana seperti pada kejadian Pemilu sebelumnya masih saja terjadi banyak pelanggaran baik pidana maupun administrasi, dan banyak kasus tersebut tidak terselasikan oleh lembaga yang berwenang yaitu KPU dan Kepolisian, dan kemudian hal ini kembali diperkuat dari adanya survey kinerja Bawaslu yang dilakukan oleh ICW dan Perludem Tahun 2016 secara online, dimana responden yang terdiri dari akademisi/praktisi, jurnalis, dan Civil Society Organization (CSO) yang dinilai mempunyai concern isu atau penge-

${ }^{13}$ Lihat alinea 4 Penjelasan Undang-Undang Nomor 15 Tahun 2011 Tentang Penyelenggaraan Pemilihan Umum. tahuan atau keahlian yang berkaitan dengan penyelenggaraan Pemilu mengatakan menilai bahwa regulasi teknis pengawasan tahapan (57\%) dan regulasi teknis penanganan pelanggaran peserta Pemilu (54\%) yang dibuat Bawaslu menimbulkan multitafsir dalam pengimplementasiannya. Selain itu, $73 \%$ responden menilai bahwa regulasi teknis penyelesaian sengketa Pemilu yang dibuat Bawaslu menimbulkan multitafsir dalam pengimplementasiannya, dengan demikian dapat dikatakan bahwa kehadiran Bawaslu sebagai sebuah lembaga pengawas ini perlu diperkuat kewenangannya dalam penegakan hokum pada penyelenggara Pemilu, merupakan sebuah terobosan yang dapat dimaksimalkan pengimplementasiannya, mengingat pentingnya penegakan hukum Pemilu yang selama ini sangat tidak efektif.

Dengan tingginya kasus pelanggaran administrasi dan pidana serta banyaknya rekomendasi kasus dari Bawaslu yang terabaikan oleh KPU dan Kepolisian, hal ini membuktikan bahwa permasalahan serius yang dihadapi bangsa Indonesia ialah terletak dalam kualitas penegakan aturan hukum Pemilu, khususnya dalam penyelenggaraan Pemilu di Indonesia, namun hal ini belumlah didukung dengan konsep sistem penegakan hukum Pemilu yang bersifat fungsional.

Perlunya penguatan kewenangan Bawaslu dalam penegakan hukum Pemilu pada penyelenggaraan Pemilu di Indonesia ini muncul akibat dari tingginya angka kasus pelanggaran administrasi dan pidana serta penanganannya yang tidak efektif oleh lembaga yang berwenang dalam hal ini yakni KPU dan Kepolisian pada penyelenggaraan Pemilu, selain hal tersebut di atas Penguatan kewenangan Bawaslu ini sejalan dengan konsep Negara Hukum Pancasila yang diterapkan di Indonesia, di mana konsep negara hukum (the rule of law) yang ditegaskan di dalam Pasal 1 ayat (3) Undang-Undang Dasar 1945, yang bersumber dari pokok-pokok pikiran pembukaan UndangUndang Dasar 1945, di mana meletakkan Pancasila sebagai falsafah Negara Indonesia yang memiliki "posisi ganda" dalam sistem hukum nasional, yakni sebagai cita hukum (rechtside) yang memiliki fungsi konstitutif serta fungsi 
regulatif, dan berkedudukan sebagai sebuah norma dasar (grundnorm). ${ }^{14}$

Pernyataan di atas ini sejalan dengan apa yang dikatakan oleh Satjipto Rahardjo, di mana ciri dari Negara Hukum Pancasila ialah rule of moral atau rule of justice, selain itu penerapan konsep negara hukum (the rule of law) di Indonesia tidak lah serta merta dapat menerapkan secara mutlak seperti di mana tempat konsep negara hukum (the rule of law) ini tumbuh dan berkembang, yakni di Eropa, karena sebagaimana diketahui bersama bahwa konsep the rule of law ini bukan merupakan sebuah institusi yang netral, karena sangat terkait dengan wawasan sosial hubungan antar manusia, masyarakat dan negara, sehingga perlu adanya penyesuaian dengan ciri dan karakteristik dari Negara Indonesia, pernyataan ini pun sejalan dengan adanya penyandingan konsep negara hukum dengan konsep kedaulatan rakyat (demokrasi), sebagaimana yang dinyatakan secara eksplisit di dalam UndangUndang Dasar 1945, dengan demikian maka kedaulatan hukum yang diletakkan dan berpijak pada kedaulatan rakyat, maka dapat dibuat suatu hipotesis, bahwa kedaulatan hukum bukanlah ditujukan semata-mata untuk kepentingan hukum itu sendiri, namun harus ditujukan dan berpihak kepada masyarakat, ${ }^{15}$ terkait dengan peranan Bawaslu dalam penegakan hukum Pemilu pada penyelenggaraan Pemilu di Indonesia.

\section{Penguatan Bawaslu Sebagai Ius Contituendum}

Perlunya penguatan Bawaslu dalam penegakan hukum Pemilu ini sesungguhnya memiliki sebuah hal positif yang mengarah kepada sebuah solusi baru yang menjawab masalah-masalah yang ada karena Bawaslu ini adalah pihak pertama yang tahu secara pasti bahwa benar-benar terjadi suatu pelanggaran pada Pemilu, namun hal ini tidak dibarengi dengan regulasi yang memadai, karena dalam Undang-Undang Nomor 15 Tahun 2011 Tentang Penyelenggaraan Pemilu, hanya menyebutkan bahwa Bawaslu berfungsi sebagai

${ }^{14}$ I Dewa Gede Atmadja, et.al, Membangun Hukum Yang Bermartabat (Malang, 2013), hlm. 115.

${ }^{15}$ Bambang Widjojanto, "Negara Hukum, Korupsi dan Hak Asasi Manusia: Suatu Kajian Awal", Jurnal Hukum Prioris Universitas Trisakti Jakarta, No. I/Vol. 3, Tahun 2012, hlm. 30. pihak yang menerima laporan dugaan pelanggaran terhadap pelaksanaan peraturan perundangundangan mengenai Pemilu, kemudian menyampaikan temuan dan laporan kepada KPU untuk ditindak lanjuti dalam konteks kasus pelanggaran administrasi dan meneruskan temuan dan laporan yang bukan menjadi kewenangannya kepada instansi yang berwenang yaitu Kepolisian dalam konteks kasus pelanggaran pidana dalam Pemilu.

Dengan demikian secara umum yang melatarbelakangi perlunya penguatan kewenangan Bawaslu dalam penegakan hukum Pemilu pada penyelenggaraan Pemilu di Indonesia, sebagaimana yang telah diulas dalam pembahasan sebelumnya dan juga sebagaimana yang terdapat dalam bahan-bahan hukum yang dikumpulkan, maka akan mengerucut kepada 2 (dua) pokok permasalahan yakni dari sisi Kelembagaan Bawaslu, dan Sisi Kewenangan Bawaslu dalam upaya penegakan hukum Pemilu. Penggolongan kedalam dua pokok permasalahan ini dilakukan agar dapat melihat secara esensial mengenai perlunya penguatan kewenangan yang melatarbelakangi peranan Bawaslu dalam penyelenggaraan Pemilu di Indonesia.

Dari sisi kelembagaan Bawaslu, masalah yang dihadapi yaitu posisi Panwaslu Kabupaten/ kotayang masih $A d H o c$, sebagaimana yang diatur dalam pasal 69 Ayat 1 Undang-Undang Nomor 15 Tahun 2011 Tentang Penyelenggaraan Pemilihan Umum. Dimana Panwaslu Kota/ Kabupaten dibentuk pada 1 (satu) bulan sebelum tahapan Pemilu Legislatif dan berakhir 2 (dua) bulan setelah berlangsungnya tahapan penyelenggaraan Pemilu. Ketentuan ini berdampak pada keterlambatan atau kurang efektifnya proses pengawasan di setiap tahapan Pemilihan Umum Legislatif, dimana Panwaslu hanya memiliki waktu yang singkat dalam pengawasan, sehingga kemungkinan belum selesainya pengawasan Pemilihan Umum Legislatif yang dimulai dari proses menyediakan logistik Pemilu, proses Pemilihan, hingga penghitungan suara dapat terjadi.

Sebagai Lembaga yang menangani laporan dugaan pelanggaran Pemilu terlebih dahulu dengan waktu masa kinerja Panwaslu yang singkat memicu kurang efektifnya kinerja dalam hal menangani laporan dugaan tindak Pidana Pemilihan 
Umum Legislatif tersebut. Di sisi lain, banyak terdapat laporan-laporan yang tidak terselesaikan oleh pihak Panwaslu sendiri, karena membutuhkan proses yang panjang serta tingkat ketelitian dalam menganalisa laporan kasus dugaan tindak pidana tersebut sangatlah membutuhkan tenaga kerja yang banyak dan mampu bertanggung jawab terhadap proses pengawasan dan pengklarifikasian tersebut, untuk nantinya dilaporkan atau direkomendasikan kepada pihak Kepolisian dan KPU

Sementara dari sisi efektivitas kewenangan Bawaslu dalam upaya penegakan hukum Pemilu, Bawaslu disini hanya sebagai pemberi laporan kepada KPU untuk ditindak lanjuti dalam konteks kasus pelanggaran administrasi dan meneruskan temuan dan laporan yang bukan menjadi kewenangannya kepada instansi yang berwenang yaitu Kepolisian dalam konteks kasus pelanggaran pidana dalam Pemilu atas temuan dan laporan yang diterima. Terkait dengan bayak Rekomendasi dan laporan kasus yang diterlantarkan dan tidak ditindaklanjuti, Bawaslu juga tidak memiliki kewenangan dalam memberikan tekanan kepada pihak KPU dan Kepolisian agar kasus yang telah dikaji dan direkomendasikan tersebut diusut sampai tuntas hal tersebut memberikan dampak yang mengakibatkan mengemukanya kasus pelanggaran-pelanggaran baik administrasi dan pidana setiap penyelenggaraan Pemilu. Hal utama yang menyebabkan mengapa pihak KPU dan Kepolisian tidak menyelesaikan kasus pelanggaran yang direkomendasi, karena terbatasnya waktu yang dimiliki oleh Bawaslu dalam mengkaji dan mengolah banyaknya temuan dan laporan pelanggaran, sehingga laporan atau rekomendasi tersebut kurang dalam banyak hal sehingga pihak kepolisian dan KPU menolak bahkan mengabaikannya. Disisi lain Bawaslu sendiri, KPU dan Kepolisian juga kewalahan dalam menerima laporan dan kemudian menangani banyaknya pelanggaran dalam Pemilu dengan terbatasnya waktu dalam menyelesaikan kasus-kasus tersebut.

Secara keseluruhan perlunya penguatan kewenagan Bawaslu dalam penegakan hukum pada penyelenggaraan Pemilu di Indonesia, merupakan sebuah ius constituendum (hukum yang dicita-citakan), guna membentuk sebuah konsep penegakan hukum Pemilu yang efektif, khususnya dalam penyelenggaraan Pemilu, karena melihat tingginya harapan masyarakat akan terwujudnya penyelenggaraan Pemilu yang lebih baik dan jauh dari pelanggaran-pelanggaran, sehingga kedepannya sangatlah perlu untuk melakukan sebuah pembenahan dalam sistem penegakan hukum Pemilu di Indonesia, dengan memasukkan sebuah konsep penguatan kewenangan Bawaslu dalam penegakan hukum Pemilu, khususnya dalam penyelenggaraan Pemilu, melalui pembenahan regulasiyang memadai baik hal ini akan dapat memberikan sebuah perubahan baik dalam perbaikan konsep demokrasi di Indonesia, dan juga sebagai sebuah wujud konsistensi terhadap konsep demokrasi Pancasila yang diterapkan di Indonesia,selaras yang disampaikan Friedman, ${ }^{16}$ bahwa sistem hukum terdiri dari substansi hukum (legal substance), struktur hukum (legal structure) dan budaya hukum (legal culture). Sinergistas bekerjanya ketiga komponen hukum tersebut, diharapkan membuat proses Pemilu/Pemilukada semakin baik, agar tidak ada lagi "pembiaran" proses pelanggaran yang terjadi dalam Pemilu/Pemilukada yang menciderai asas langsung, umum, bebas, rahasia, jujur dan adil. Sehubungan dengan itu maka sistem penegakan hukum dalam undang-undang harus lebih responsive memberi ruang termasuk memberi penguatan kewenangan kapada Bawaslu dalam penegakan hukum Pemilu.

\section{B. Analisis Bentuk Penguatan Kewenangan Bawaslu Dalam Penegakan Hukum Pemilu}

Secara umum berdasarkan bahan hukum yang telah dikumpulkan, maka terkait dengan bentuk penguatan kewenangan Bawaslu dalam penegakan hukum Pemilu pada penyelenggaraan Pemilu di Indonesia, akan menawarkan konsep yang menjadi indikator dalam bentuk penguatan kewenangan ini yang dapat memperkuat dan cenderung akan sangat efektif implementasinya dalam penegakan hukum pada penyelenggaraan Pemilu di Indonesia, terkait dengan solusi dalam peranan Bawaslu dalam penyelenggaraan Pemilu di Indonesia, ialah dengan melakukan sebuah

${ }^{16}$ Arif Wibowo, Menata Ulang Sistem Penyelesaian Sengketa dan Pelanggaran Pemilukada dalam buku Demokrasi lokal, (Jakarta, Konstitusi Press, 2013) hlm. 117. 
perubahan terhadap Undang-Undang Nomor 15 Tahun 2011 Tentang Penyelenggaraan Pemilu, yang di mana mengatur mengenai fungsi dan kewenangan yang dimiliki oleh Bawaslu, sebelumnya lembaga ini hanyalah dibentuk untuk melakukan pengawasan Pemilu dan menerima laporan untuk selanjutnya dikaji dan direkomendasikan atau dilaporkan kepada lembaga yang berwenang, yakni dengan menguatkan kewenangan dan fungsi dari Bawaslu dalam hal:

1. Kedudukan Panitia Pengawas Pemilihan Umum Kabupaten/Kota haruslah mengalami perubahan yang awalnya bersifat $A d H o c$ menjadi bersifat tetap. Sebagaimana yang terjadi pada kedudukan Bawaslu provinsi, mengingat peran Panwaslu sangat Strategis.

2. Fungsi pengawasan dikuatkan dengan kerjasama antara Bawaslu pemantau Pemilu, peserta Pemilu, pemilih, organisasi kemasya- rakatan, media massa, lembaga survei, sukarelawan, dan organisasi masyarakat sipil pada umumnya

3. Bawaslu berwenang menegakkan pelanggaran administrasi Pemilu, termasuk menerima pengaduan, menyelidiki dugaan pelanggaran, menyidangkan dan menetapkan apakah terbukti terjadi pelanggaran atau tidak, beserta menetapkan sanksinya apabila terbukti

4. Bawaslu menjadi penyidik dan penuntut atas dugaan pelanggaran pidana Pemilu yang berdampak langsung terhadap hasil Pemilu.

5. Memperpanjang masa pelaporan dan pengkajian, khususnya tindak pidana Pemilu

Berikut komparasi bentuk penguatan kewenangan bawaslu sebelum dan sesudah penguatan dalam tabel dibawah ini:

\section{Tabel 11. Kewenangan Bawaslu Dalam Penegakan Hukum Pemilu Sebelum dan Setelah Penguatan}

\begin{tabular}{|l|l|}
\hline $\begin{array}{l}\text { Kewenangan Bawaslu dalam } \\
\text { Penegakan Hukum Sebelum } \\
\text { Penguatan }\end{array}$ & \multicolumn{1}{|c|}{$\begin{array}{c}\text { Kewenangan Bawaslu dalam Penegakan Hukum Setelah } \\
\text { Penguatan }\end{array}$} \\
\hline $\begin{array}{l}\text { Mengawasi tahapan } \\
\text { menyelenggaraan Pemilu }\end{array}$ & $\begin{array}{l}\text { Bawaslu bekerja sama dengan pemantau Pemilu, peserta Pemilu, } \\
\text { pemilih, organisasi kemasyarakatan, media massa, lembaga } \\
\text { survei, sukarelawan, dan organisasi masyarakat sipil pada } \\
\text { umumnya }\end{array}$ \\
\hline $\begin{array}{l}\text { Menerima laporan dugaan } \\
\text { pelanggaran terhadap } \\
\text { pelaksanaan peraturan } \\
\text { perundang-undangan } \\
\text { mengenai Pemilu; }\end{array}$ & $\begin{array}{l}\text { Menerima laporan dugaan pelanggaran terhadap pelaksanaan } \\
\text { peraturan perundang-undangan mengenai Pemilu serta mengkaji } \\
\text { kasus-kasus tertentu, yang secara sosiologis berpengaruh } \\
\text { terhadap proses penegakan hukum Pemilu; }\end{array}$ \\
\hline $\begin{array}{l}\text { Menyampaikan temuan dan } \\
\text { laporan pelanggaran } \\
\text { administrasi kepada KPU } \\
\text { untuk ditindak lanjuti; }\end{array}$ & $\begin{array}{l}\text { Menegakkan pelanggaran administrasi Pemilu, termasuk } \\
\text { menerima pengaduan, menyelidiki dugaan pelanggaran, } \\
\text { menyidangkan dan menetapkan apakah terbukti terjadi } \\
\text { pelanggaran atau tidak, beserta menetapkan sanksinya apabila } \\
\text { terbukti }\end{array}$ \\
\hline $\begin{array}{l}\text { Meneruskan temuan dan } \\
\text { laporan yang bukan menjadi } \\
\text { kewenangannya kepada } \\
\text { instansi yang berwenang. }\end{array}$ & $\begin{array}{l}\text { Bawaslu menjadi penyidik dan penuntut atas dugaan } \\
\text { pelanggaran pidana Pemilu. Dalam Tubuh Bawaslu baik di } \\
\text { Pusat, Provinsi dan Kabupaten/Kota dimasukkan unsur } \\
\text { kepolisian dan kejaksaan yang ditugaskan khusus menangani } \\
\text { tindak pidana Pemilu agar proses penanganan kasus } \\
\text { tindakpidana Pemilu berjalan efektif, pihak inilah yang secara } \\
\text { nyata melakukan penyidikan dan penuntutan berdasarkan } \\
\text { pengarahan Bawaslu. Disini Bawaslu memiliki wewenang untuk } \\
\text { mengangkat Penyidik, dan melakukan penuntutan. }\end{array}$ \\
\hline
\end{tabular}


Sebelum membahas lebih jauh mengenai perubahan penguatan kewenangan Bawaslu ini perlu dikaji dari sisi kelembagaan bahwa kedudukan Panitia Pengawas Pemilihan Umum Kabupaten/ Kota haruslah mengalami perubahan yang awalnya bersifat Ad Hoc menjadi bersifat tetap. Sebagaimana yang terjadi pada kedudukan Bawaslu provinsi, mengingat peran Panwaslu sangat Strategis. Ini sangat perlu, karena Panwaslu yang bersifat $A d H o c$ yang diatur dalam pasal 69 Ayat 1 Undang-Undang Nomor 15 Tahun 2011 Tentang Penyelenggaraan Pemilihan Umum. Dimana Panwaslu dibentuk pada 1 (satu) bulan sebelum tahapan Pemilu dan berakhir 2 (dua) bulan setelah berlangsungnya tahapan penyelenggaraan Pemilu. Ketentuan ini berdampak pada keterlambatan atau kurang efektifnya proses pengawasan di setiap tahapan Pemilihan Umum Legislatif. Dimana Panwaslu hanya memiliki waktu yang singkat dalam pengawasan, sehingga kemungkinan belum selesainya pengawasan Pemilihan Umum Legislatif yang dimulai dari proses menyediakan logistik Pemilu, proses Pemilihan, hingga penghitungan suara dapat terjadi. Sebagai lembaga yang menangani laporan dugaan pelanggaran Pemilu terlebih dahulu dengan waktu masa kinerja Panwaslu yang singkat memicu kurang efektifnya kinerja dalam hal menangani laporan dugaan tindak Pidana Pemilihan Umum Legislatif tersebut. Di sisi lain, banyak terdapat laporan-laporan yang tidak terselesaikan oleh pihak Panwaslu sendiri, karena tentu saja membutuhkan proses yang panjang serta tingkat ketelitian dalam menganalisa laporan kasus dugaan tindak pidana tersebut sangatlah membutuhkan tenaga kerja yang banyak dan mampu bertanggung jawab terhadap proses pengawasan dan pengklarifikasian tersebut, maka dari itu Panwaslu kota atau kabupaten haruslah mengalami perubahan yang awalnya bersifat $A d H o c$ menjadi bersifat tetap layaknya Bawaslu pusat maupun provinsi sehingga kinerja dalam hal pengawasan dan penegakan hukum Pemilu dapat berjalan efektif.

\section{Peran Partisipasif Masyarakat Dalam Upaya Penguatan Bawaslu}

Dari unsur fungsi pengawasan sangat perlu untuk melibatkan masyarakat seperti pemantau Pemilu, peserta Pemilu, pemilih, organisasi kemasyarakatan, media massa, lembaga survei, sukarelawan, dan organisasi masyarakat sipil pada umumnya karena peran mereka sangat membantu apabila dimaksimalkan. Karena peran serta unsur masyarakat dalam fungsi pengawasan ini akan mempengaruhi terealisasinya penguatan kewenangan Bawaslu dalam penyelenggaraan Pemilu di Indonesia dimana hal tersebut pula memiliki pengaruh terhadap penegakan hukum penyelenggara Pemilu di Indonesia, dalam hal ini ialah partisipasi masyarakat, tolak ukur partisipasi masyarakat di sini dapat diukur dari adanya peran serta masyarakat dalam mengawasi penyelenggaraan Pemilu, selama ini tingkat partisipasi masyarakat dalam penegakan hukum maupun pengawasan penyelenggara Pemilu masih sangat minim, hal ini dapat dilihat dari data Bawaslu tentang penangan pelanggaran Pemilu yang dipaparkan sebelumya, di mana laporan tentang pelanggaran Pemilu sangat didominasi oleh peserta Pemilu.

Peran serta masyarakat dalam fungsi pengawasan dan persoalan penegakan hukum Pemilu dan dalam mendorong peranan Bawaslu di Indonesia selaras dengan apa yang disampaikan oleh Fatkhurohman, yang menyebutkan bahwa sebuah pelaksanaan model demokrasi deliberatif yang bertitik taut dengan pemikiran Jurgen Habermas yang menawarkan model demokrasi sehingga memungkinkan rakyat terlibat dalam proses pembuatan hukum dan kebijakan politik, kemudian konsep demokrasi deliberatif ini mengingatkan kembali kepada ajaran dasar Demokrasi Pancasila yang sama-sama menekankan persoalan musyawarah. ${ }^{17}$ Maka kunci dari bentuk penguatan kewenangan yang berasal dari peran serta masyarakat ini dapat dilakukan dengan membentuk sebuah pola yang sinergis yang memungkinkan keterlibatan masyarakat secara nyata dalam proses pengawasan Pemilu, karena selama ini proses keterlibatan masyarakat baik dalam pembentukan dan pelaksanaan sebuah fungsi hanyalah bersifat semu dan terkesan formalitas semata.

Fungsi pengawasan yang melibatkan unsur masyarakat ini dapat dikatakan sebagai sebuah faktor yang memiliki pengaruh yang cukup besar

${ }^{17}$ Fatkhurohman, "Mengukur Kesamaan Paham Demokrasi Deliberatif, Demokrasi Pancasila dan Demokrasi Konstitusional", Jurnal Konstitusi Universitas Widyagama Malang, No. 2/Vol. IV, November 2011, hlm. 48-54 
dalam upaya penguatan kewenangan Bawaslu, seperti yang dikatakan oleh Sirajuddin ${ }^{18}$ bahwasannya masyarakat harus menjadi masyarakat yang kritis dan partisipasif dalam rangka mewujudkan Pemilu yang jujur dan adil, karena tanpa daya kritis dan partisipasi masyarakat aturan Pemilu dan Penyelenggara Pemilu dalam hal ini Bawaslu maupun KPU tidak akan efektif. Selain itu perubahan terhadap sebuah sistem pengawasan yang efektif dalam konteks penguatan kewenangan Bawaslu yang diterapkan di Indonesia hanyalah dapat terwujud dari adanya peran serta masyarakat yang menginginkan adanya sebuah perbaikan dari penegakan hukum Pemilu yang ada di Indonesia, hal ini sejalan dengan adanya konsep hukum responsif yang dikemukakan Philipe Nonet dan Philip Selznick, yang mengatakan bahwa hukum haruslah dikonsepkan untuk dapat memenuhi tuntutan-tuntutan terhadap kebutuhan sosial yang mendesak dan masalahmasalah keadilan keadilan sosial. ${ }^{19}$

Sebuah catatan penting yang harus diilhami dari adanya upaya peningkatan peran serta masyarakat di sini ialah, bahwa untuk mewujudkan hal tersebut tentunya mengingatkan kembali kepada sebuah konsep masyarakat madani (civil society), di mana merupakan sebuah masyarakat yang memiliki kebebasan yang dilaksanakan dengan penuh tanggungjawab, bebas dari rasa takut, dan senantiasa mengembangkan kerja sama yang didasarkan atas kepercayaan, sehingga muncul inisiatif dan partisipasi warga masyarakat dalam kehidupan berbangsa dan bernegara. ${ }^{20}$

Konsep masyarakat madani (civil society) hanya akan dapat terwujud jika manusia sebagai subjek masyarakat tersebut telah berkembang secara manusiawi berkat pendidikan, dan dengan adanya perkembangan kearah pembentukan konsep masyarakat madani (civil society) maka hal ini akan menjadi suatu pranata penting dalam hal memperkuat demokrasi, sehingga demokrasi akan semakin mengakar dalam masyarakat, jika negara berhasil mewujudkan masyarakat madani

\footnotetext{
${ }^{18}$ Sirajuddin dan Solehoddin "Partisipasi Lembaga Swadaya Masyarakat Dalam Mengontrol Praktek Politik Uang Pada Pemilihan Langsung Kepala Daerah”, “, Jurnal Konstitusi Universitas Widyagama Malang, No. 1/Vol. III, Juni 2010, hlm. 89.

${ }^{19}$ Abdul Muktie Fadjar, Teori-Teori Hukum Kontemporer (Malang, 2013), hlm. 49.

${ }^{20}$ Zamroni, Teaching Social Studies. A Reader (Yogyakarta, 2008), hlm. 17.
}

(civil society), ${ }^{21}$ namun dengan sebuah catatan bahwa konsep demokrasi yang diterapkan haruslah bersumber dari nilai-nilai Pancasila, karena perwujudan dari demokrasi melalu Pemilu, merupakan sebuah penerapan konsep demokrasi Pancasila dalam sistem politik, struktur politik, dan kultur politik, sebagai sebuah konsekuensi bahwa Pemilu merupakan sebuah bagian yang tidak dapat dipisahkan dari bagian kehidupan bermasyarakat, berbangsa dan bernegara, ${ }^{22}$ sehingga bentuk penguatan kewenangan Bawaslu ini akan menjadi sebuah konsistensi dari adanya sistem penegakan hukum Pemilu yang baik, sebagaimana yang terdapat dalam konsep demokrasi Pancasila, yang akan bermuara kepada perwujudan cita-cita dan tujuan Negara Indonesia. ${ }^{23}$

\section{Transformasi Bawaslu Sebagai Lembaga Penegakan Hukum Pemilu yang Efektif}

Dalam konteks menegakkan pelanggaran administrasi Pemilu, dan pidana Pemilu perlu dilakukan suatu betuk penyederhanaan sistem penegak hukum dan penyelesaian sengketa Pemilu agar dapat mewujudkan efektifnya penegakan hukum Pemilu yang selama ini menjadi problem utama. Jadi fokus yang diperhatikan bahwa penyelesaian pelanggaran administrasi maupun pidana diproses melalui satu pintu melalui Bawaslu dimana dalam konteks pelanggaran administrasi, Bawaslu berwenang menerima pengaduan, menyelidiki dugaan pelanggaran, menyidangkan dan menetapkan apakah terbukti terjadi pelanggaran atau tidak, beserta menetapkan sanksinya apabila terbukti sementara untuk menangani pelanggaran pidana Pemilu, Bawaslu menjadi penyidik dan penuntut atas dugaan pelanggaran pidana Pemilu. Dalam Tubuh Bawaslu baik di Pusat, Provinsi dan Kabupaten/Kota dimasukkan unsur kepolisian dan kejaksaan yang ditugaskan khusus menangani tindak pidana Pemilu agar proses penanganan kasus tindakpidana Pemilu berjalan efektif, pihak inilah yang secara nyata melakukan penyidikan dan penuntutan berdasarkan pengarahan Bawaslu.

\footnotetext{
${ }^{21}$ Ibid., hlm. 28.

${ }^{22}$ Sri Handayani Retna Wardhani, "Penerapan Demokrasi Pancasila Dalam Pemilu Legislatif Tahun 2009”, Jurnal Konstitusi Universitas Islam Indonesia Yogyakarta, No. 1/Vol II, Juni 2009, hlm. 50.

${ }^{23}$ Ibid., hlm. 54.
} 
Disini Bawaslu memiliki wewenang untuk mengangkat Penyidik, dan melakukan penuntutan, layaknya lembaga independen seperti KPK dan tentunya dapat dilakukan dengan mendasarkan kepada sebuah konsep perbandingan hukum terkait penegakan hukum Pemilu yang diselenggarakan oleh negara lain, salah satu negara yang kemudian menerapkan sebuah sistem yang berfungsi untuk menyelesaikan permasalahan pidana yang timbul selama penyelenggaraan Pemilu ialah Inggris, di mana di negara ini diterapkan sebuah lembaga khusus Pemilu yaitu lembaga khusus “Special Crime Division” yang salah satu kompetensinya ialah menyelesaikan semua bentuk pelanggaran Pidana dari tahap penyidikan dan penuntutan, hal ini mengisyaratkan bahwa penguatan kewenangan Bawaslu dalam penegakan hukum Pemilu dilandasi dengan adanya kebutuhan dari sebuah negara, sehingga bentuk penguatan ini lebih menkankan kepada dinamika sosial dan politik yang terjadi di sebuah negara, dengan melihat fakta demikian maka perlu dilakukan penguatan kewenangan Bawaslu dalam meyelesaikan pelanggaran pidana maupun administrasi pada penyelenggaraan Pemilu.

Selanjutnya Bawaslu perlu diberi waktu lebih dalam penyelesaian pelanggaran, karena dipertimbangkan hal-hal berikut:

Pertama, yang berada di jalur cepat atau "fast track" semestinya hanya penyelesaian pelanggaran administrasi, sengketa dalam proses, dan sengketa hasil Pemilu karena penyelesaian masalah-masalah ini memang sangat mempengaruhi tahapan-tahapan Pemilu yang ada yang memang ada limitasi waktunya jelas (misalnya penetapan peserta Pemilu, pencalonan, kampanye, pemungutan dan penghitungan suara, dan penetapan hasil). Jika tidak dibatasi waktu secara tegas dan jelas, proses Pemilu bisa tersendat dan tertunda dan pada akhirnya menggangu jalannya pemerintahan. Sedangkan, untuk tindak pidana Pemilu, masalahnya adalah berkaitan dengan penemuan adanya suatu tindak pidana, memproses orang yang disangka/dituduh melakukan tindak pidana itu, dan menjatuhkan pidana karena ia melakukan kesalahan. Semua ini tidak hanya menyangkut perbuatannya tetapi juga kesalahan orangnya. Tentu ini berbeda dengan penyelesaian untuk pelanggaran administrasi maupun sengketa. Yang dicari dalam penyelesaian pidana adalah kebenaran materiil.

Tentu semua harus dilakukan secara cermat, teliti, hati-hati, serta tidak bisa tergesa-gesa. Jika targetnya adalah waktu, akan banyak tindak pidana Pemilu yang tidak tersentuh hukum, dan hak memidana dari negara akan hilang atas tindak pidana-tindak pidana itu. Dampak lainnya, akan hilangnya kepercayaan masyarakat pada hukum dan negara yang membiarkan banyak tindak pidana lolos dari jerat hukum karena lewat masa yang luar biasa pendek, yaitu 7 (tujuh) hari. Jadi, kesimpulannya, pembuat UU telah keliru menyamaratakan batasan waktu pelaporan 7 (tujuh) hari untuk semua jenis pelanggaran atau sengketa.

Seharusnya tindak pidana Pemilu memiliki batas waktu daluwarsa yang lebih masuk akal (jika disesuaikan dengan di Pasal 78 KUHP, daluwarsanya 6 tahun atau 12 tahun, bukan hanya 7 hari).

Kedua, seandainya pun pembuat UU ingin mempercepat proses atau setidaknya membatasi lamanya penyelesaian tindak pidana Pemilu, semestinya pembatasan itu dilakukan pada tindakan penyidikan, penuntutan, atau pemeriksaan di pengadilan, dan bukan dengan membatasi masa pelaporan 7 (tujuh) hari sesudah kejadian. Ketentuan untuk membatasi masa penyidikan, penuntutan, atau pemeriksaan di pengadilan bisa dilakukan sebagaimana juga diatur dalam beberapa undang-undang khusus lainnya.

Dengan adanya pembatasan waktu ini, diharapkan ada kepastian bahwa tindak pidana Pemilu akan selesai sesuai dengan waktu yang masuk akal dan tidak berlarut-larut. Akan tetapi, batasan waktu tidak seharusnya diterapkan pada masa pelaporan tindak pidana Pemilu, sebab ada kalanya suatu peristiwa baru diketahui beberapa hari, minggu, bulan, atau bahkan tahun, setelah dilakukannya tindakan itu. Untuk menjamin adanya keadilan dan kesamaan, ketentuan itu disesuaikan saja dengan ketentuan mengenai daluwarsa dalam Pasal 78 KUHP. ${ }^{24}$ Atau, jika pembuat UU ingin mengadakan aturan yang Pidana.

${ }^{24}$ Undang-undang No. 1 tahun 1946 Tentang peraturan Hukum 
khusus, bisa saja batas waktu itu dibuat lebih masuk akal, misalnya 1-6 tahun sesudah kejadian.

Singkatnya, pengaturan batasan waktu dalam penanganan pelanggaran Pemilu yang singkat justru merusak asas Pemilu, khususnya agar Pemilu dijalankan secara jujur dan adil. Sehingga sangat perlu untuk memberikan waktu lebih kepada Bawaslu dalam hal penanganan dan pengkajian laporan tersebut.

\section{Pengaruh Political Will Dalam upaya Penguatan Kewenangan Bawaslu}

Terealisasinya hal diatas, yakni memberikan penambahan kewenangan kepada Bawaslu harus didukung dengan regulasi yang memadai berupa produk undang-undang, sehingga Bawaslu memiliki kewenangan secara atribusi melalui ketentuan undang-undang untuk melaksanakan penegakan hukum Pemilu, yang kemudian nantinya dalam penerapan bentuk penguatan kewenangan tersebut akan sangat dipengaruhi oleh faktor utama, di mana faktor ini sebagian besar bersumber dari pemangku kekuasaan, yang dalam hal ini ialah pihak legislator dan penguasa, dalam faktor utama ini yang sangat berpengaruh ialah dari sisi political will (kemauan politik) dari pihak legislator dan penguasa, karena lahirnya sebuah aturan atau norma hukum yang melegitimasi penguatan kewengangan Bawaslu dalam penegakan hukum pada penyelenggaraan Pemilu di Indonesia sangatlah bergantung kepada political will, pemilihan faktor utama yang diakibatkan oleh pemangku kepentingan ini, dikarenakan lahirnya perkembangan dan perbaikan konsep penyelenggaraan pemilihan umum, sangatlah didominasi oleh political will (kemauan politik) dari para pemangku kepentingan, dan faktor inilah yang menjadi sebuah kunci dari perlunya penguatan kewenangan lembaga Bawaslu yang berfungsi sebagai penegak hukum Pemilu di Indonesia, karena adanya keinginan dan harapan dari para pemangku kepentingan untuk memperbaiki kualitas penyelenggaraan Pemilu di Indonesia, hal ini sejalan dengan apa yang dikatakan oleh Abdul Muktie Fadjar, bahwa perkembangan pelaksanaan Pemilu di Indonesia sangatlah dipengaruhi oleh perkembangan sistem politik atau ketatanegaraan yang diterapkan, sehingga baik itu asas-asas Pemilu, peserta Pemilu, penyelenggaraan Pemilu, maupun macam-macam Pemilu juga akan terus mengalami dinamika yang ada. ${ }^{25}$

Dalam perkembangan penyelenggaraan Pemilu di Indonesia, konsep penguatan kewenangan Bawaslu dalam penegakan hukum Pemilu ini sesungguhnya sudah harus menjadi salah satu fokus pembahasan dalam mengupayakan perbaikan dalam penyelenggaraan Pemilu di Indonesia, namun hal ini belum diwujudkan, di mana penguatan kewenangan Bawaslu tidak ditegaskan melalui undang-undang sebagai sebuah lambaga yang lebih memiliki kewenangan dalam hal penegakan hukum, namun hanya menjalankan fungsi selayaknya tukang pos atau memberikan rekomendasi berdasarkan laporan atau temuan yang diterima kepada lembaga yang berwenang, sehingga dengan demikian bentuk penguatan kewenangan Bawaslu ini mampu direalisasi dengan adanya political will dari pihak legislator dan penguasa, mengingat kondisi Pemilu saat ini yang diwarnai dengan banyaknya pelanggaran yang terjadi.

Sebagaimana yang telah dibahas dalam pembahasan sebelumnya bahwa penguatan kewenangan Bawaslu ini merupakan sebuah ius constituendum (hukum yang dicita-citakan), maka untuk merealisasikan hal tersebut, memunculkan political will dari pihak legislator dan penguasa, merupakan sebuah keniscayaan, sehingga penguatan Bawaslu dalam penyelenggaraan Pemilu di Indonesia dapat menjadi pilihan yang tak terelakkan.

Secararingkas, terealisasinya bentuk penguatan kewenangan Bawaslu dalam penyelenggaraan Pemilu di Indonesia, sangat dipengaruhi faktor utama, di mana faktor utama ini terkait dengan political will (keamuan politik) dari pihak legislator dan penguasa, apakah mampu untuk lebih melihat perlunya terealisasi bentuk penguatan kewenangan Bawaslu dalam penegakan hukum Pemilu di Indonesia sebagai sebuah jawaban dari ketidakefektifan penegakan hukum dalam penyelenggaraan Pemilu, sehingga dengan adanya political will ini akhirnya akan mampu untuk memperbaiki kualitas Pemilu di Indonesia, karena kemauan politik (political will) ini akan mampu melahirkan

${ }^{25}$ Abdul Muktie Fadjar, Pemilu: Perselisihan Hasil Pemilu \& Demokrasi (Malang, 2013), hlm. 13. 
sebuah akses perbaikan kearah yang lebih baik dari penyelenggaraan Pemilu di Indonesia, kemudian faktor eksternal ini terkait dengan adanya partisipasi masyarakat dalam mempengaruhi pembentukan sebuah kebijakan, dan perombakan hukum yang masih berlaku, sehingga akan mempengaruhi kemunculan political will dari pihak legislator dan penguasa untuk melaksanakan Bawaslu dalam penyelenggaraan Pemilu di Indonesia.

Penambahan kewenangan dan fungsi Bawaslu ini akan menjadi sebuah ius constituendum dan akan menggantikan ius constitutum, dan hal ini akan mengarahkan kepada sebuah arah perbaikan sistem penegakan hukum Pemilu yang selama ini berlaku di Indonesia, selain itu jika menilik kebelakang pada amanat reformasi, bahwa aturan atau hukum sangat diharapkan untuk dapat berperan membawa masyarakat kearah perubahanperubahan yang dikehendaki, karena mengingat fungsi hukum adalah sebagai alat untuk mengatur dan mengarahkan masyarakat merupakan sebuah perwujudan dari peran hukum sebagai "a tool of social engineering", maka hal inilah yang membukakan sebuah peluang besar untuk berlangsungnya perubahan hukum secara dinamis. ${ }^{26}$

Selain hal sebagaimana yang tersebut di atas, jika melihat kembali tujuan mendasar dari etika politik, yang mana bertujuan untuk mengarahkan ke arah hidup yang lebih baik, kebersamaan, dan bermanfaat bagi orang lain dalam rangka memperluas kebebasan serta membangun atau membentuk lembaga-lembaga yang adil, ${ }^{27}$ maka sejatinya Penguatan kewenangan Bawaslu dalam penegakan hukum Pemilu pada penyelenggaraan Pemilu di Indonesia dapat dinilai sebagai sebuah dialektika hukum yang mengarah kepada sebuah perbaikan format penyelenggaraan Pemilu di Indonesia.

Terkait dengan penambahan kewenangan dan fungsi dari Bawaslu, hal ini telah diatur secara tegas di dalam Undang-Undang Dasar yakni Pasal 22 E ayat (6) yang menyebutkan bahwa: "Ketentuan lebih lanjut tentang pemilihan umum

${ }^{26}$ Satjipto Rahardjo, Hukum dan Perubahan Sosial, (Yogyakarta, 2009), hlm. 134-135.

${ }^{27}$ Wahyu Wibowo, "Komunikasi Politik Sebagai Keniscayaan Etis", Jurnal Poelitik, Kajian Politik dan Masalah Pembangunan, No.1/Vol 4, Tahun 2008, hlm. 165. diatur dengan undang-undang”, makna yang dapat diambil dalam rumusan pasal tersebut ialah bahwa kepentingan dan aspirasi rakyat juga diwadahi dan dijadikan pedoman dalam pembentukan undang-undang melalui wakilnya di DPR, ${ }^{28}$ maka jelaslah bahwa kemauan politik (political will) dan peran serta masyarakat, merupakan sebuah kunci utama untuk dapat mendorong terealisasinya bentuk Penguatan kewenangan Bawaslu dalam penegakan hukum Pemilu.

\section{PENUTUP}

Berdasarkan uraian yang terdapat dalam analisis hasil di atas, maka dapat diperoleh beberapa kesimpulan, yakni sebagai berikut:

1. Urgensi mendasar yang melatarbelakangi penguatan kewenangan Bawaslu dalam penegakan hukum pada penyelenggaraan pemilihan umum di Indonesia dapat dilihat dari poin utama yakni, tingginya angka kasus pelanggaran administrasi dan pidana serta penaganannya yang tidak efektif oleh lembaga yang berwenang dalam hal ini yakni KPU dan Kepolisian pada penyelenggaraan Pemilu, ini dikarenakan oleh: pertama Kelembagaan pengawas Pemilu di tingkat Kabupaten/Kota yang bersifat kepanitiaan (Ad Hoc) berimplikasi pada kurang maksimalnya kinerja pengawas Pemilu terutama dalam hal penegakkan hukum Pemilu. Kedua batasan waktu yang sempit untuk Bawaslu dalam mengkaji laporan pelanggaran Pemilu, karena dengan membatasi waktu pelaporan hanya 7 (tujuh) hari sesudah kejadian kejadia hanya akan bermakna "kepastian", yaitu dengan "menghanguskan" semua laporan yang dilakukan lebih dari 7 (tujuh) hari, selain itu pembatasan waktu dalam penanganan pelanggaran Pemilu dalam Undang-Undang Pemilu tidak disertai defenisi dan penjelasan mengenai hari tersebut, apakah hari kerja atau termasuk hari libur dan yang diliburkan (cuti bersama).

2. Bentuk penguatan kewenangan Bawaslu dalam penyelenggaraan pemilihan umum di Indonesia yaitu dengan beberapa poin berikut, pertama fungsi pengawasan dikuatkan dengan

${ }_{28}$ Sekretariat Jenderal MPR RI, Panduan Pemasyarakatan UUD 1945 dan Ketetapan MPR RI (Jakarta, 2011), hlm. 138. 
kerjasama antara Bawaslu pemantau Pemilu, peserta Pemilu, pemilih, organisasi kemasyarakatan, media massa, lembaga survei, sukarelawan, dan organisasi masyarakat sipil pada umumnya, kedua, Penyederhanaan sistem penegakan hukum dan penyelesaian sengketa Pemilu yaiut Bawaslu berwenang menegakkan pelanggaran administrasi Pemilu, dan menjadi penyidik dan penuntut atas dugaan pelanggaran pidana Pemilu yang berdampak langsung terhadap hasil Pemilu dan ketiga, perlu diberikan waktu yang lebih kepada Bawaslu dalam hal penanganan masalah pelanggaran Pemilu, mengingat banyaknya kasus yang ada setiap kali penyelenggaran Pemilu yang tidak relevan dengan batasan waktu yang diberi oleh Undang-undang dalam konteks tersebut, ini agar mengantisipasi terjadinya terbengkalai dan tidak terurusnya kasus yang sudah ditemui. Keempat Kedudukan Panitia Pengawas Pemilihan Umum Kabupaten/Kota haruslah mengalami perubahan yang awalnya bersifat $A d H o c$ menjadi bersifat tetap. Terealisasinya bentuk penguatan kewenangan Bawaslu tersebut tentu sangat dipengaruhi oleh political will (kemauan politik) dari pihak legislator dan penguasa, dalam melihat urgensi dari peranan Bawaslu dalam penyelenggaraan pemilihan umum di Indonesia, sebagai sebuah jawaban atas adanya kondisi tingginya kasus pelanggaran Pemilu dan banyak pula kasus tersebut yang tidak terselesaikan dengan baik yang tejadi di Indonesia, sehingga akan mampu menciptakan political will dari pihak legislator dan penguasa untuk mewujudkan penguatan kewenangan Bawaslu sebagai sebuah ius constituendum (hukum yang dicita-citakan) dalam penyelenggaraan pemilihan umum di Indonesia, kemudian solusi dalam penguatan kewenangan Bawaslu dalam penegakan hukum pada penyelenggaraan Pemilu di Indonesia ialah dengan melakukan perubahan terhadap Undang-Undang Nomor 15 Tahun 2011 Tentang Penyelenggaraan Pemilu, dengan memberikan penambahan kewenangan dan fungsi dari Bawaslu, yang semula hanya melaksanakan fungsi pengawasan dan pemberi rekomendasi pelanggaran Pemilu pada KPU apabila bersifat administrasi dan kepada Kepolisian apabila bersifat pidana, menjadi lembaga yang lebih aktif dalam menegakan hukum Pemilu secara langsung, sehingga mampu memperbaiki format penegakan hukum di Indonesia, terutama dalam penyelenggaraan Pemilu.

\section{DAFTAR PUSTAKA}

\section{BUK:}

Asshiddiqie, Jimly, 2014, Pengantar Ilmu Hukum Tata Negara, Jakarta: Rajagrafindo Persada , 2010, Perkembangan dan Konsolidasi Lembaga Negara Pasca Reformasi, Jakarta: Sinar Grafika

Atmadja, I Dewa Gede. et.al. 2013. Membangun Hukum Yang Bermartabat. Malang: Setara Press

Budiardjo, Miriam. 2008. Dasar-Dasar Ilmu Politik. Jakarta:PT. Gramedia Pustaka Utama

Dellyana,Shant. 1988, Konsep Penegakan Hukum. Yogyakarta: Liberty

Fadjar, Abdul Muktie. 2013. Pemilu: Perselisihan Hasil Pemilu \& Demokrasi. Malang: Setara Press

2013. Teori-Teori Hukum Kontemporer. Malang: Setara Press

Fatah, Eep Saefulloh. 2000. Zaman Kesempatan: Agenda-Agenda Besar Demokratisasi Pasca Orde Baru. Bandung: Mizan

Gaffar, Janedjri M. 2013. Politik Hukum Pemilu. Jakarta: Konstitusi Press

Gunawan, Setiardja, A. 1990. Dialektika Hukum dan Moral dalam Pembangunan Masyarakat Indonesia. Yogyakarta: Kanisius

Hakim, Lukman. 2010. Kedudukan Hukum Komisi Negara Di Indonesia. Malang: Program Pasca Sarjana Universitas Brawijaya Malang

Hartono. Penyidikan \& Penegakan Hukum Pidana Melalui Pendekatan Hukum Progresif; Sinar Grafika Jakarta, 2010

Hikam, Moch. AS., 1997, Redemokratisasi dan Civil Society, Jakarta: LP3ES 
Ibrahim, Jhon,2006, Teori dan Metodologi Penelitian Hukum Normatif, Malang: Banyumedia Publishing

Kusnardi, Moh \& Harmaily Ibrahim. 1988. Pengantar Hukum Tata Negara Indonesia. Jakarta: Sinar Bakti

Liddle, R. William. 1992. Pemilu-Pemilu Orde Baru: Pasang Surut Kekuasaan Politik. Jakarta: LP3ES

Malarangeng, Andi Alfian. 1999. Komisi Pemilihan Umum: Dalam Kajian Pemilu 1999 Jakarta: Puskap, Depdagri dan Biro Humas KPU

Manan, Bagir, 2000, Wewenang Provinsi, Kabupaten dan Kota dalam Rangka Otonomi Daerah. Bandung: Fakultas Hukum Universitas Padjajaran Press

Marzuki, Peter Mahmud. 2006, Penelitian Hukum, Edisi 1 Cet. Ke- 1, Jakarta: Kencana

Muchsan, 1992, Sistem Pengawasan Terhadap Perbuatan Aparat Pemerintah dan Peradilan Tata Usaha Negara Indonesia, Yogyakarta: Liberty

Mulyosudarmo, Suwoto. 1990. Kekuasaan dan Tanggung Jawab Presiden Republik Indonesia, Suatu Penelitian Segi-Segi Teoritik dan Yuridis Pertanggungjawaban Kekuasaan. Surabaya: UNAIR

Rahardjo, Satjipto. 2003. Sisi-Sisi Lain Dari Hukum Indonesia. Jakarta: Kompas . 2009. Hukum dan Perubahan Sosial, Yogyakarta: Genta Publishing .2010. Masalah Penegakan Hukum (Suatu Tinjauan Sosiologis), Sinar Baru, Bandung

Ridwan, Juniarso dan Achmad Sodik Sudrajat, 2012, Hukum Administrasi Negara dan Kebijakan Pelayanan Publik, Jakarta: Nuansa

Ridwan HR, 2013, Hukum Administrasi Negara, PT Raja Grafindo Persada, Jakarta

Sadjijono, 2008, Memahami Beberapa Bab Pokok Hukum Administrasi, Yogyakarta: LaksBang Pressindo
Santoso, Topo, et.al. 2006. Penegakan Hukum Pemilu, Praktik Pemilu 2004 dan Kajian Pemilu 2009-2014. Jakarta: Perludem . et.al. 2011 Penangan Pelanggaran Pemilu, Jakarta : Kemitraan

Sardini, Nurhidayat, 2009, Pedoman Pengawasan Pemilu, Jakarta: Election-M

Siagian,Sondang. P. 1990. Filsafat Administrasi, Jakarta: Gunung Agung

Soekanto,Soerjono. 2013. Faktor-Faktor yang Mempengaruhi Penegakan Hukum, Raja Grafindo Persada

Soekanto, Soerjono \& Sri Mamudji. 1990. Penelitian Hukum Normatif Suatu Tinjauan Singkat. Jakarta: Rajawali Press

Soemitro,Ronny Hanitijo. 1988, Metodologi Penelitian Hukum dan Jurimetri, Jakarta: Ghalia Indonesia

Sunggono, Bambang. 2012. Metode Penelitian Hukum. Jakarta: Rajawali Press

Suswantoro, Gunawan. 2016, Mengawal Penegak Demokrasi, Jakarta: Erlangga

Sutrisno, Bernard Dermawan, 2002, Konflik Politik KPU Dalam Pemilu 1999, Jakarta: Mutiara Sumber Widya

Supriyatno, Didik, Veri Junadi, Devi Darmawan, 2012, Penguatan Bawaslu, Optimalisasi Posisi, Organisasi, dan Fungsi dalam Pemilu 2014, Jakarta: Perludem.

Surbakti, Ramlan. 1992, Memahami Ilmu Politik. Jakarta: PT Grasindo

Tim Peneliti Perludem. 2006. Efektifitas Panwas: Evalauasi Pengawasan Pemilu 2004, Disertai Resume Laporan Pengawasan Pemilu 2004. Jakarta: Peruldem

Tutik, Titik Triwulan, 2010. Konstruksi Hukum Tata Negara Indonesia Pasca Amandemen UUD 1945, Jakarta: Prenada Media.

Wibowo, Arif. 2013 Menata Ulang Sistem Penyelesaian Sengketa dan Pelanggaran Pemilukada-dlm buku Demokrasi local, Jakarta, Konstitusi Press

Situmorang,Victor M. 1998, Aspek-aspek Hukum Pengawasan Melekat Dalam Lingkungan Aparatur Pemerintah. Jakarta: Rineka Cipta 
Zamroni, 2008. Teaching Social Studies. A Reader. Yogyakarta: Graduete Program The State University of Yogyakarta

\section{JURNAL ILMIAH:}

Asshiddiqie, Jimly. 2013. "Pengenalan Dewan Kehormatan Penyelenggara Pemilihan Umum" (Makalah Dalam Forum Rapat Pimpinan Kepolisian Republik Indonesia, Jakarta, Februari 2013)

Fatkhurohman, 2011. "Mengukur Kesamaan Paham Demokrasi Deliberatif, Demokrasi Pancasila dan Demokrasi Konstitusional", Jurnal Konstitusi Universitas Widyagama Malang, No. 2/Vol. IV, November 2011

Hakim, Lukman. 2011. Kewenangan Organ Negara Dalam Penyelengaraan Pemerintahan. Jurnal Konstitusi. Puskasi Universitas Widyagama Malang, Vol IV No. 1, Juni 2011.

Harun, Rafly. 2017. "Politik Keledai Pemilu", dalam Kompas, 07 Juni 2017

Satriawan, Iwan. 2016. Pengawasan Pemilukada oleh Rakyat, Jurnal Bawaslu Vo. 2 Edisi I Tahun 2016

Surbakti, Ramlan. 2016. "Penegakan Hukum Pemilu", dalam Kompas, 16 Desember 2016

Sekretariat Jenderal MPR RI, Panduan Pemasyarakatan UUD 1945 dan Ketetapan MPR RI Jakarta, 2011

Siregar, Fritz Edward. "Urgensi Peningkatan Peran Bawaslu Dalam Pemilu Serentak”, dalam Konstitusi, Oktober 2016

Sirajuddin dan Solehoddin "Partisipasi Lembaga Swadaya Masyarakat Dalam Mengontrol Praktek Politik Uang Pada Pemilihan Langsung Kepala Daerah”, “, Jurnal Konstitusi Universitas Widyagama Malang, No. 1/Vol. III, Juni 2010.

Tim Peneliti Perludem. 2013. Jurnal Pemilu dan Demokrasi Seri 6: Memotret Penegakan Hukum Pemilu 2014.

Wardhani, Sri Handayani Retna. 2009. "Penerapan Demokrasi Pancasila Dalam Pemilu Legislatif Tahun 2009”, Jurnal Konstitusi Universitas Islam Indonesia Yogyakarta, No. 1/Vol II, Juni 2009.
Syawawi, R. dan Khoirunnisa Agustiyati. 2010. Membunuh Demokrasi Lokal, Mengembalikan Pemilihan Kepala Daerah kepada $D P R D$. Jurnal Pemilu dan Demokrasi, Vol. 4, November 2010

Yosa, 2010, Pengawasan Sebagai Sarana Penegekan Hukum Administrasi Negara, Jurnal Kementerian Dalam Negeri

Wibowo,Wahyu. "Komunikasi Politik Sebagai Keniscayaan Etis", Jurnal Poelitik, Kajian Politik dan Masalah Pembangunan, No.1/Vol 4, Tahun 2008,

Widjojanto, Bambang. 2012 "Negara Hukum, Korupsi dan Hak Asasi Manusia : Suatu Kajian Awal", Jurnal Hukum Prioris Universitas Trisakti Jakarta, No. I/Vol. 3, Tahun 2012

Zulkarnain. 2009. "Kajian Keriminologi terhadap Tindak Pidana Pemilu: Membedah Akar-Akar Pemicu Tindak Pidana Pemilu Dalam Sistem Penyelenggaraan Pemilu 2009 dan Problematika Penyelesaiaannya", dalam Jurnal Konstitusi Universitas Widyagama, No. 2/Vol. II, November 2009. Malang: Puskasi Universitas Widyagama

\section{WEBSITE:}

Bawaslu, "Laporan Hasil Pengawasan Pemilu Tahun 2014" dalam http://www.Bawaslu. go.id/id/hasil-pengawasan-pemilu/laporanhasil-pengawasan-pemilu-tahun-2014, diakses tgl. 19 Februari 2017

Kania Sekar Asih, Sistem Pemilihan Presiden Indonesia, https//:kminoz.wordpress.com/ dikutip pada tanggal 15 Maret 2017

http://sonny-tobelo.blogspot.com//teorikewenangan, diakses tanggal 17 Maret 2017

Syafrudin, Ateng, Menuju Penyelenggaraan Pemerintahan Negara yang Bersih dan Bertanggung Jawab, Jurnal Pro Justisia Edisi IV, hlm. 22, dalam http//www. gogle.com//kewenangan dalam ilmu hukum, diakses tanggal 18 Maret 2017

http://www.hukumonline.com/berita/baca/ 1t5469b3c9cb3 f3/penegakan-hukumpemilu-perlu-dibenahi diakses pada Tanggal 19April 2017 
http://www.beritasatu.com/nasional/424222ketua-bawaslu-akui-penegakan-hukumpemilu-masih-lemah.html diakses pada Tanggal 19April 2017

http://news.okezone.com/read/2017/04/18/338/ 1670008/tindak-pelanggaran-pilkadabelum-efektif-bawaslu-disarankan-ini diakses pada Tanggal 19 April 2017

http://www.antikorupsi.org/sites/antikorupsi. org/files/doc/Kajian/. diakses pada Tanggal 19 April 2017

http://www.nurhidayatsardini.com/detail.php? id $=325$ diakses tanggal 20 April 2017

https://www.kpk.go.id/id/tentang-kpk/fungsidan-tugas. Diakses tanggal 21 April 2017

http://www.electoralcommission.org.uk/findinformation-by-subject/electoral-fraud/ electoral-fraud-vulnerabilities-review? $\mathrm{a}=$ 155335 diakses pada tanggal 26 April 2017

\section{PERATURAN PERUNDANG-UNDANGAN DAN RISALAH PERSIDANGAN:}

Undang-Undang Dasar Negara Republik Indonesia 1945.

Undang-Undang No. 1 Tahun 1946 Tentang Peraturan Hukum Pidana.

Undang-Undang Nomor 2 Tahun 1980 Tentang Perubahan Atas Undang-Undang Nomor 15 Tahun 1969 Tentang Pemilihan Umum Anggota-Anggota Badan Permusyawaratan/ Perwakilan Rakyat Sebagaimana Telah Diubah Dengan Undang-Undang Nomor 4 Tahun 1975.
Undang-Undang No. 30 Tahun 2002 Tentang Komisi Pemberantasan Tindak Pidana Korupsi.

Undang-Undang Republik IndonesiaNomor 12 tahun 2003 Tentang Pemilihan umum anggota dewan perwakilan rakyat, Dewan perwakilan daerah, dan dewan perwakilan rakyat daerah.

Undang-Undang Nomor 22 Tahun 2007 tentang Penyelenggara Pemilihan Umum.

Undang-Undang Nomor 15 Tahun 2011 Tentang Penyelenggaraan Pemilihan Umum.

Undang-Undang Nomor 8 Tahun 2012 tentang Pemilihan Umum Anggota Dewan Perwakilan Rakyat, Dewan Perwakilan Daerah, dan Dewan Perwakilan Rakyat Daerah.

Undang-Undang Nomor 22 Tahun 2007 Tentang Penyelenggaraan Pemilihan Umum.

Peraturan Dewan Kehormatan Penyelenggara Pemilihan Umum Nomor 2 Tahun 2012 Tentang Pedoman Beracara Kode Etik Penyelenggara Pemilihan Umum.

Putusan Mahkamah Konstitusi Nomor 11/PUUVIII/2010 tentang Pengujian UndangUndang Nomor 22 Tahun 2007 tentang Penyelenggara Pemilihan Umum terhadap Undang-Undang Dasar Negara Republik Indonesia 1945.

Putusan Mahkamah Konstitusi Nomor 108109/PHPU.B-VII/2009 tanggal 12 Agustus 2009. 
